\title{
Identification of a BACE1 Binding Peptide Candidate for the Prevention of Amyloid Beta in Alzheimer's Disease
}

\author{
Justin Read ${ }^{\mathrm{a}, \mathrm{b}} \quad$ Cenk Suphioglu ${ }^{\mathrm{a}}$ \\ aNeuroAllergy Research Laboratory (NARL), School of Life and Environmental Science, Faculty of \\ Science, Engineering and Built Environment, Deakin University, Waurn Ponds, VIC, Australia, 'bHotchkiss \\ Brain Institute, Cumming School of Medicine, University of Calgary, Health Science Centre, Calgary, AB, \\ Canada
}

\section{Key Words}

BACE1 • Alzheimer's disease $\cdot A D \cdot$ Amyloid beta $(A \beta) \cdot$ Phage display $\bullet$ Biopanning

\begin{abstract}
Background/Aims: Amyloid plaques, generated during the progression of Alzheimer's disease, cause major neurological deficits due to substantial cell toxicity and death. The underlying cause of plaque generation stems from cleavage of the amyloid precursor protein (APP) by $\beta$-secretase (BACE1). A resulting amyloid- $\beta$ (A $\beta$ ) fragment forms aggregates to produce the main constituent of a plaque. Methods: Phage display and biopanning techniques were used to identify a 12-mer peptide that had a natural affinity for the BACE1 enzyme. The peptide was translated from phage DNA and synthetically produced. The peptide, at concentrations of $1 \mathrm{nM}, 10 \mathrm{nM}$ and $100 \mathrm{nM}$, was used to confirm binding by direct assay. Non-specific binding to BACE2, renin and cathepsin D was tested by direct binding assay. A BACE1 activity assay was used to determine the peptide effect on cleavage of an APP substrate. Treatment of SY5Y cells with the peptide was used to determine toxicity and prevention of $A \beta 40$ and $A \beta 42$ production. Results: After identification and synthetic production, the peptide exhibited a strong affinity for BACE1 at nanomolar concentrations in the direct assay. In case of non-specific binding to homologous BACE2, renin and cathepsin $D$, the peptide showed minor binding but was nullified when in solution with BACE1. The peptide addition to a BACE1 activity assay was able to significantly reduce the amount of substrate cleavage. SY5Y cells, when treated with the peptide, did not show any detrimental morphological changes while being able to reduce the production of natural $A \beta 40$ and $A \beta 42$. Even under stressed conditions $\left(\mathrm{H}_{2} \mathrm{O}_{2}\right.$ treatment) where the $A \beta$ production was higher, the peptide was still able to significantly reduce the effect of BACE1 while not effecting cell viability. Conclusion: The identified peptide exhibited strong binding to $B A C E 1$ in vitro and was able to reduce production of $A \beta$, suggesting a favourable BACE1 inhibitor for future refining and characterisation.




\section{Cellular Physiology Cell Physiol Biochem 2019;53:413-428 \\ \begin{tabular}{ll|l} 
and Biochemistry & $\begin{array}{l}\text { DOblished online: } 16 \text { August } 2019 \\
\text { Publis }\end{array}$ & $\begin{array}{l}\text { C } 2019 \text { The Author(s). Published by } \\
\text { Cell Physiol Biochem Press GmbH\&Co. KG }\end{array}$
\end{tabular} \\ Read et al.: Peptide Inhibitor of BACE1 for AD}

\section{Introduction}

Alzheimer's disease (AD) is a neurodegenerative disease, mainly affecting the elderly generations. Disease progression shows clinical symptoms of, but not limited to, memory impairment, difficulty in performing common tasks, loss of motor functioning and lack of spatial awareness. Vast neuronal cell apoptosis and brain atrophy to both cortical and subcortical brain regions, as a cause of these impairments, eventually leads to death (1, 2). Dissection and histopathological examination of human brains with extensive cerebral amyloidoses classified plaque constituents containing a unique amyloid fibril protein (3). This protein fragment would later be characterised as a protein of approximately 40 residues that can form multimeric aggregates (4). Gene cloning and cDNA analysis of the amyloid monomers determined that they were part of a larger protein and a biproduct of enzymatic modification. That protein was later characterised as the amyloid precursor protein (APP), a 695-amino acid cell surface receptor $(5,6)$.

The processing of APP occurs by the sequential cleavage by three proteases called secretases, $\alpha-, \beta$-, and $\gamma$-. The $N$-terminal fragment of APP can be cleaved by either $\alpha$ - or $\beta$-secretase creating a non-amyloidogenic (non-pathogenic) or amyloidogenic (pathogenic) product $(7-10)$. The $C$-terminal subsequently gets cleaved by $\gamma$-secretase releasing the remnants of APP. Cleavage at the alpha site by $\alpha$-secretase produces a $C$-terminal fragment of 83 residues (C-83), leaving a longer remaining fragment, which is non-amyloidogenic (11). Instead, cleavage by $\beta$-secretase (BACE1), 16 amino acids towards $N$-terminal at the beta site, produces a shorter soluble APP- $\beta$ (sAPP $\beta$ ) fragment (9). Subsequent processing of the remaining $C$-terminal fragment of 99 residues (C-99) by $\gamma$-secretase release an insoluble amyloid fragment $(A \beta)$.

Additionally, Presenilin 1 and 2 of $\gamma$-secretase will then determine the length of $A \beta$ by producing a 38-43 amino acid fragment. The differing lengths in which sAPP $\beta$ is processed can determine the way plaques are formed by a higher or lower propensity to aggregate (12-17). Aggregation from these monomers, specifically $A \beta 42$, becomes part of a feedback loop that promotes plaque propagation (18). This aggregation around synapses decreases dendritic spine density and increases synaptotoxicity but the effective inhibition of BACE1 could prevent these plaque forming units from being produced (19-21).

Initially, $\mathrm{AD}$ was defined by amyloid plaque deposition however, research has expanded to encompass neurofibrillary tangles, brain atrophy, compromised blood brain barrier and genetic factors like apolipoprotein E4 (ApoE4) (22-25). In addition, the inhibition of BACE1 and prevention of amyloid based plaques has a significant effect on disease progression $(26,27)$. An early detection of disease will undoubtedly increase the chance of remission, as plaque generation and $A \beta$ is hypothesized to be most effective in the early stages of disease.

Currently, there is no effective treatment for Alzheimer's disease or the deposition of $A \beta$, only methods to relieve symptoms. Current attempts to generate viable synthetic and organic inhibitors have been thwarted by poor blood brain barrier permeability, retention in plasma, adverse toxicity, and BACE1 binding specificity.

To address this, we utilised the phage display and biopanning technique to identify a 12 amino acid peptide that could not only bind to BACE1 specifically but prevent the enzymatic ability to cleave APP. Biopanning and phage display has been successful in acquiring positive binding peptides to numerous targets like interleukin-4 receptor, alkaline phosphatase, hepsin, tissue metalloproteinases and tyrosinase (28-32). Defining a construct with effective binding properties is the proactive direction of the current study to refining an effective new candidate for AD. 


\section{Cellular Physiology Cell Physiol Biochem 2019;53:413-428 \\ \begin{tabular}{ll|l} 
and Biochemistry & $\begin{array}{l}\text { DOI: 10.33594/000000147 } \\
\text { Published online: } 16 \text { August } 2019\end{array}$ & $\begin{array}{l}\text { C } 2019 \text { The Author(s). Published by } \\
\text { Cell Physiol Biochem Press GmbH\&Co. KG }\end{array}$
\end{tabular} \\ Read et al.: Peptide Inhibitor of BACE1 for AD}

\section{Materials and Methods}

\section{Phage Display Binding to BACE1}

Recombinant human BACE1 (Sigma-Aldrich, USA) was diluted to $50 \mu \mathrm{g} / \mathrm{ml}$ in blocking buffer $(0.1 \mathrm{M}$ $\mathrm{NaHCO}_{3}$ (pH 8.6), $5 \mathrm{mg} / \mathrm{ml}$ bovine serum albumin (BSA), $0.02 \% \mathrm{NaN}_{3}$ ) and added to a single well of a 96well microtitre plate and incubated overnight at $4^{\circ} \mathrm{C}$ with shaking. The solution was discarded and replaced with blocking buffer and incubated at $4^{\circ} \mathrm{C}$ for a further 60 minutes. The well was washed six times with $0.1 \%$ TBS-T (50mM Tris-HCl (pH 7.5), 150mM NaCl, 0.1\% (v/v) Tween-20) before adding a 100-fold representation of the phage display peptide library (New England Biolabs, USA). The library was incubated with the BACE1 target for 60 minutes at room temperature with gentle rocking. The well was washed a further 10 times with $0.1 \%$ TBS-T. The unbound phage in solution were discarded and the bound phage eluted by adding glycine buffer $(0.2 \mathrm{M}$ glycine- $\mathrm{HCl}(\mathrm{pH} 2.2), 1 \mathrm{mg} / \mathrm{ml} \mathrm{BSA})$ to the microtitre plate well and gently rocked for 7 minutes. The solution was transferred to a microcentrifuge tube and neutralised with $1 \mathrm{M}$ Tris- $\mathrm{HCl}$ ( $\mathrm{pH}$ 9.1), which formed the unamplified eluate. Luria broth (LB) culture was inoculated with a single ER2738 E. coli colony picked from a stock plate and incubated at $37^{\circ} \mathrm{C}$ to early-log phase $\left(\mathrm{OD}_{600}\right.$ $0.01-0.05)$. $100 \mu \mathrm{l}$ of unamplified phage was added to the culture and incubated with vigorous shaking at $37^{\circ} \mathrm{C}$ for 4.5 hours. The culture was transferred to a sterile tube and pelleted by centrifugation at $12,000 \mathrm{xg}$ for 10 minutes at $4^{\circ} \mathrm{C}$. The upper $80 \%$ of the supernatant was precipitated overnight at $4^{\circ} \mathrm{C}$ with $\mathrm{PEG} / \mathrm{NaCl}$ $(20 \%(\mathrm{w} / \mathrm{v})$ polyethylene glycol- $8000,2.5 \mathrm{M} \mathrm{NaCl})$. The phage were pelleted by centrifugation at $12,000 \mathrm{xg}$ for 15 minutes at $4^{\circ} \mathrm{C}$. The supernatant was discarded and the pellet re-suspended in TBS $(50 \mathrm{mM}$ Tris- $\mathrm{HCl}$ ( $\mathrm{pH} 7.5), 150 \mathrm{mM} \mathrm{NaCl}$ ). The suspension was pelleted at 17, 000xg for 10 minutes. The supernatant was transferred to a new microcentrifuge tube along with 1/6 volume PEG/NaCl and allowed to precipitate on ice for 60 minutes. The phage were pelleted at 17, 000xg for 10 minutes with the supernatant being discarded and the pellet re-suspended in TBS. This formed the amplified eluate. An ER2738 culture grown to mid-log phase $\left(\mathrm{OD}_{600} \sim 0.5\right)$ was combined with unamplified phage diluted to $10^{-4}$ in LB media and plated in 10 -fold increments from $10^{-1}$ and amplified phage diluted to $10^{-11}$ in LB media and plated in 10 -fold increments from $10^{-8}$. Dilutions were pre-incubated with the mid-log phase E. coli host strain for 10 minutes. Pour plates were constructed using molten top agar $(10 \mathrm{~g} / \mathrm{l}$ bacto-tryptone, $5 \mathrm{~g} / \mathrm{l}$ yeast extract, $85 \mathrm{mM}$ sodium chloride, $7 \mathrm{~g} / \mathrm{l}$ agar) mixed with the phage/E. coli suspension and added to the already prepared IPTG/Xgal plates. Plates were incubated for 18 hours at $37^{\circ} \mathrm{C}$ and plaque forming units per millilitre (pfu/ml) calculated. All biopanning preparations were maintained in sterile environments of a KS18 Class II safety cabinet (ThermoFisher Scientific) to minimise contamination.

\section{Biopanning Rounds and DNA Sequencing Preparation}

Biopanning second round steps were replicated from original phage display protocol but instead of the library being introduced to the immobilised target, the amplified phage from the previous round was added. The $\mathrm{pfu} / \mathrm{ml}$ of amplified eluate was used to maintain the input of $\sim 1 \times 10^{11}$ phage virions into the subsequent rounds. Tween-20 concentrations for wash steps, prior to the phage incubation, were increased by $0.1 \%(\mathrm{v} / \mathrm{v})$ for every subsequent round. The fifth round of biopanning was not amplified and instead the unamplified eluate was titred as previously described. Within an 18-hour incubation time, twelve individual plaques were picked and transferred to individual ER2738 broth cultures, grown to early-log phase (OD $_{600}$ $0.01-0.05$ ) and incubated for 4.5 hours at $37^{\circ} \mathrm{C}$ with vigorous shaking. The cultures were transferred to microcentrifuge tubes and pelleted by centrifugation at $14,000 \mathrm{xg}$ for 30 seconds. $500 \mu \mathrm{l}$ of supernatant was mixed with PEG/NaCl and incubated for 20 minutes at room temperature. The PEG precipitation was pelleted by centrifugation at $14,000 \mathrm{xg}$ for 10 minutes at $4^{\circ} \mathrm{C}$. The pellet was suspended in iodine buffer (10mM Tris-HCl (pH 8.0), 1mM EDTA, 4M sodium iodide ( $\mathrm{NaI}$ )). $70 \%$ (v/v) ethanol was added to the tube and incubated for 15 minutes at room temperature. The precipitate was centrifuged at $14,000 \times \mathrm{xg}$ for 10 minutes at $4^{\circ} \mathrm{C}$ and the supernatant discarded. The remaining pellet was suspended in TE buffer $(1 \mathrm{M}$ Tris (pH 8.0), 0.5M EDTA). The precipitated DNA concentration was quantified using a ND-1000 NanoDrop spectrophotometer (ThermoFisher Scientific).

\section{Amplification and Purification of Phage DNA for Sequencing}

The purified DNA samples were individually amplified using the BigDye ${ }^{\circ}$ Terminator v3.1 Cycle Sequencing Kit (ThermoFisher Scientific). The kit was assembled for templates as recommended by the 


\section{Cellular Physiology Cell Physiol Biochem 2019;53:413-428 \\ \begin{tabular}{l|l|l} 
and Biochemistry $10.33594 / 000000147$ & Published 2019 The Author(s). Published by
\end{tabular} \\ Read et al.: Peptide Inhibitor of BACE1 for AD}

supplier. Samples were added to an MJ Research PTC-100 thermocycler (Bio-Rad Laboratories) and run for 25 cycles of $96^{\circ} \mathrm{C}$ for 10 seconds, $50^{\circ} \mathrm{C}$ for five seconds and $60^{\circ} \mathrm{C}$ for four minutes. PCR products were transferred to microcentrifuge tubes and mixed with $2 \mu \mathrm{l}$ of $125 \mathrm{mM}$ EDTA, $2 \mu \mathrm{l}$ of $3 \mathrm{M}$ sodium acetate and $50 \mu \mathrm{l}$ of $100 \%$ ethanol and incubated at room temperature for 15 minutes. The tubes were centrifuged at $2500 \mathrm{xg}$ for 30 minutes. The supernatant was discarded and $70 \mu \mathrm{l}$ of $70 \%$ ethanol added to the pellet and centrifuged at $1650 \mathrm{xg}$ for 15 minutes. The bulk of the supernatant was removed with remaining left to evaporate in a class II safety cabinet allowing the pellet to dry on the base of tube, ready for sequencing. The nucleic acids resulting from the sequencing were viewed using Finch TV software (Geospiza Inc.). The synthetic peptide was produced with and without a biotin label by Auspep Pty. Ltd. (Australia).

\section{Direct Assay Determining Binding of Biopanning Candidate to BACE1}

Recombinant BACE1, as used in the phage display, was immobilised on wells of a microtitre plate. The peptide, produced from the result of the phage display and biopanning, was biotin labelled and added to BACE1-coated wells at concentrations of $1 \mathrm{nM}, 10 \mathrm{nM}$ and $100 \mathrm{nM}$ and incubated for 60 minutes at room temperature with rocking. No-peptide negative controls were also included. The solution was discarded and the wells washed 3 times with 0.3\% TBS-T. Then, a 1:500 dilution of streptavidin/HRP conjugate (Amersham Biosciences) in $0.1 \%$ TBS-T was added to the wells and incubated for 60 minutes at room temperature with rocking. The solution was discarded and washed three times. For the detection, the o-phenylenediamine dihydrochloride (OPD) substrate was dissolved in phospho-citrate buffer with sodium perborate, added to all wells and incubated for 60 minutes at room temperature in the dark. The reaction was stopped with $4 \mathrm{M}$ sulfuric acid before reading the reaction on a HALO MPR-96 plate reader (Dynamica) at wavelength $492 \mathrm{~nm}$.

\section{Specificity Test of the Peptide Candidate to BACE1}

Solutions of $1 \mu \mathrm{M}$ recombinant BACE1, renin, cathepsin D and BACE2 were prepared in a $0.1 \mathrm{M} \mathrm{NaHCO}$ (pH 8.6) buffer, added to a 96-well plate and incubated overnight at $4^{\circ} \mathrm{C}$ with rocking. The solution was discarded and replaced with blocking buffer and incubated for a further hour at $4^{\circ} \mathrm{C}$. The blocking buffer was discarded and the wells washed three times with $0.1 \%$ TBS-T. Solutions containing $100 \mathrm{nM}$ biotinylated peptide were incubated for 60 minutes at room temperature with rocking. The wells were washed again 3 times with $0.3 \%$ TBS-T. Streptavidin/HRP conjugate in $0.1 \%$ TBS-T was added to the wells and incubated for 60 minutes at room temperature with rocking. The solution was then discarded and washed three times with $0.1 \%$ TBS-T. Detection was performed using the same protocol as the direct assay, described above.

\section{Competition Assay to Confirm BACE1 Specificity}

A $1 \mu \mathrm{M}$ solution of recombinant BACE1 was immobilised using the same protocol as the direct assay. During well blocking, a solution containing $1 \mu \mathrm{M}$ renin, cathepsin D and BACE2 was incubated with $100 \mathrm{nM}$ of peptide in TBS-T for 30 minutes. The plate wells were washed three times with TBS-T, replaced with the pretreatments and incubated for 60 minutes at room temperature with rocking. The wells were washed again 3 times with $0.3 \%$ TBS-T. Then, a 1:500 dilution of streptavidin/HRP conjugate (Amersham Biosciences) in $0.1 \%$ TBS-T was added to all wells and incubated for 60 minutes at room temperature with rocking. Detection was performed using the same protocol as the direct assay.

\section{BACE1 Activity Assay with Direct Binding Method}

The BACE1 activity was tested using a fluorescent FRET activity assay kit (Millipore Sigma). Instead of placing all kit elements at once into a solution, the inhibitor was immobilized on nitrocellulose. A grid, of $1 \mathrm{~cm} \times 1 \mathrm{~cm}$ squares, was marked out on a nitrocellulose membrane according to the sample numbers and the respective inhibitor concentrations. The squares, used for the BACE1 inhibition, had 10nM, 100nM or 200nM of inhibitor solution pipetted onto the centre of the respective square and allowed to dry, controls were left to dry without inhibitor. All squares were placed into $50 \mathrm{ml}$ tubes, according to inhibitor concentration, containing blocking buffer $(5 \%(\mathrm{w} / \mathrm{v})$ instant skim milk powder) and incubated for 30 minutes at room temperature with shaking. The squares were transferred to individual tubes and washed three times for 5 minutes each with Milli-Q water. The squares were then removed and placed in their respective tubes according to reaction number. The tubes contained $78 \mu \mathrm{l}$ of fluorescent assay buffer (FAB) and $20 \mu \mathrm{l}$ of the substrate, diluted 10-folded from the stock. A 40nM BACE1 solution in FAB was added to all tubes and incubated with agitation for 2 hours at $37^{\circ} \mathrm{C}$. After incubation, the nitrocellulose squares were removed 


\section{Cellular Physiology Cell Physiol Biochem 2019;53:413-428 \begin{tabular}{ll|l}
\cline { 2 - 2 } and Biochemistry $10.33594 / 000000147$ & Published online: 16 August 2019 & $\begin{array}{l}\text { (2019 The Author(s). Published by } \\
\text { Cell Physiol Biochem Press GmbH\&Co. KG }\end{array}$ \\
\cline { 2 - 3 }
\end{tabular} \\ Read et al.: Peptide Inhibitor of BACE1 for AD}

and the remaining solution transferred to a 96-well plate and read on a Fluostar Omega fluorometer (BMG Labtech) with excitation of $320 \mathrm{~nm}$ and emission $405 \mathrm{~nm}$.

\section{SY5Y Cell Culture and Treatments with the BACE1 Inhibitor}

Cryopreserved SH-SY5Y cells (Millipore Sigma, ATCC CRL-2266) were thawed in a water bath at $37^{\circ} \mathrm{C}$, transferred into media (HamsF12:EMEM (1:1), 2mM glutamine, 1\% non-essential amino acids and 15\% foetal bovine serum (FBS) (v/v)) and placed in an incubator at $37^{\circ} \mathrm{C}$ with $5 \% \mathrm{CO}_{2}$. The media was discarded and replaced after two days of incubation. Cells were seeded at $80 \%$ confluence by removing and discarding the media and washing the cell monolayer twice with PBS containing $137 \mathrm{mM} \mathrm{NaCl}, 2.7 \mathrm{mM} \mathrm{KCl}, 8.1 \mathrm{mM}$ $\mathrm{Na}_{2} \mathrm{HPO}_{4}$ and $1.47 \mathrm{mM} \mathrm{KH}_{2} \mathrm{PO}_{4}$. Cells were harvested by adding $0.25 \%$ Trypsin-ethylenediaminetetraacetic acid (EDTA) in PBS for 2 minutes before quenching with fresh media. The cells were diluted 1:10 in a new flask with fresh media.

\section{Cell Viability and Cell Number Calculation}

$200 \mu$ l of cells, after trypsinisation and quenching, were transferred to a microcentrifuge tube and pelleted at $1,000 \mathrm{xg}$ for 5 minutes to remove any traces of the remaining serum. Media was removed and the

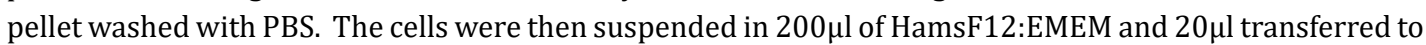
a fresh microcentrifuge tube. $20 \mu \mathrm{l}$ of trypan blue dye solution was added to the $20 \mu \mathrm{l}$ of cells and loaded into the TC10 sample chambers on the counting slide. The slide was added to the TC10 Automated Cell Counter (Bio-Rad Laboratories) and the cell viability and counts analysed.

\section{Cell Treatments}

SY5Y cells were grown to $80 \%$ confluency and harvested using $3 \mathrm{ml}$ of $0.25 \%$ trypsin/EDTA/PBS and quenched with $7 \mathrm{ml}$ of media. The cells were transferred to a six-well plate and allowed to adhere overnight. Media was pre-incubated for 24 hours with the BACE1 peptide inhibitor to $1 \mathrm{nM}, 10 \mathrm{nM}$ and $100 \mathrm{nM}$. Old media was replaced with treatment media and the cells incubated for 24 hours. Media was removed and the monolayer washed with PBS. Cells were lysed in the wells with CelLytic MT (Millipore Sigma) and protein concentration determined with a Qubit fluorometer (ThermoFisher Scientific). The lysates were used immediately in the $\mathrm{A} \beta 40$ and $\mathrm{A} \beta 42$ ELISAs.

\section{SY5Y Hydrogen Peroxide Treatment}

SY5Y cells were grown to $80 \%$ confluency, trypsinised and transferred to 6-well plates, as described above. The media was pre-treated with $200 \mu \mathrm{M}$ hydrogen peroxide $\left(\mathrm{H}_{2} \mathrm{O}_{2}\right)$ for 24 hours before adding to the cells. Testing the BACE1 inhibitor, the $\mathrm{H}_{2} \mathrm{O}_{2}$ pre-treatments contained one of a $1 \mathrm{nM}, 10 \mathrm{nM}$ and $100 \mathrm{nM}$ concentrations. After the treated cells were incubated for 24 hours, the monolayer was washed once with PBS and lysed on the plate with CelLytic MT (Millipore Sigma).

\section{Human $A \beta 40$ and AB42 ELISA with Treated SY5Y Cell Lysates}

The human A $\beta 40$ and A $\beta 42$ ELISAs (Invitrogen) were purchased as kits from ThermoFisher Scientific and performed as recommended by the supplier, following the manufacturer's instructions.

\section{Statistics}

Statistical analysis of direct ELISA, specificity test, activity assay and other ELISAs were performed as means ( $n=3$ ), comparing negative controls to the individual treatments using GraphPad Prism 7.0 software. Cell viability live cell counts were performed by the TC10 Automated Cell Counter (Bio-Rad Laboratories). Statistical significance was determined by unpaired Student's $t$-test $\left(\mathrm{p}<0.05^{*}, \mathrm{p}<0.01^{* *}, \mathrm{p}<0.001{ }^{* * *}\right.$, $\mathrm{p}<0.0001^{* * * *}$ ). 


\section{Cellular Physiology Cell Physiol Biochem 2019;53:413-428 \\ \begin{tabular}{ll|l} 
and Biochemistry & $\begin{array}{l}\text { DOl: 10.33594/000000147 } \\
\text { Published online: } 16 \text { August } 2019\end{array}$ & $\begin{array}{l}\text { O } 2019 \text { The Author(s). Published by } \\
\text { Cell Physiol Biochem Press GmbH\&Co. KG }\end{array}$ \\
\cline { 2 - 3 } &
\end{tabular} \\ Read et al.: Peptide Inhibitor of BACE1 for AD}

\section{Results}

\section{Biopanning and Phage Display}

Identification of a peptide with strong binding affinity to BACE1 was determined using the phage display and biopanning techniques. The recombinant BACE1 target was bound to a microtitre plate well while the unbiased library of peptide candidates, expressed on phage capsid, were allowed to freely bind to the large protein. Using the natural affinity to BACE1, the bound phage remained while the unbound was washed away. High affinity binders were tested over five rounds of biopanning to refine the pool down to the best candidates.

Phage titre was determined by dilution of the amplified eluate with infection of the ER2738 host strain. The pooled phage were amplified and used in the subsequent round to test candidate binding affinity. Biopanning rounds were extended from three rounds to five as a stringency requirement to refine the number of BACE1 binders. The increase in stringency represented by the Tween- 20 concentration in the wash buffer did not influence the titre produced. Across the five rounds of biopanning, titre increased from $7 \times 10^{9}$ plaque forming units per millilitre $(\mathrm{pfu} / \mathrm{ml})$ in the first round to $3 \times 10^{11}$ by the fourth. The eluate from the fifth round of biopanning was plated with the unamplified eluate to pick the individual plaques for sequencing. Of the 53 plaques produced, 12 were picked and amplified individually. None of the plated phage dilutions contained any contamination with the white, wild-type plaques, suggesting that host transduction was successful and sterile techniques were maintained. Transduction was confirmed with all 12 sequences containing the additional sequence representing the M13KE cloning vector of the phage.

\section{Phage DNA Sequencing}

All isolated DNA samples were quantified using an ND-1000 NanoDrop spectrophotometer and analysed for purity. The samples were analysed by comparing the $260 / 280 \mathrm{~nm}$ wavelengths, producing results between the expected 1.7 and 2.1 levels. The near pure DNA samples were complemented by chromatograms, which produced clearly identifiable nucleotide peaks. The inserts were identified by the KpnI/Acc65 and EagI restriction enzyme sites, where the DNA insert was ligated, then confirming the presence of the triple glycine leader sequence attached to all 12-residue peptides of the pIII surface proteins. Of the 12 plaques sampled, DNA sequencing revealed the $10^{9}$ varying sequences in the phage library had been reduced to one unanimous candidate. The sequence was analysed using a BLAST search via the National Centre for Biotechnology Information (NCBI) database for possible similarity with other proteins, peptides and inhibitors without success.

\section{Direct ELISA Determining Binding of Biopanning Candidate to BACE1}

The phage peptide identified from the sequencing was translated into a synthetic peptide and tested by direct binding assay. The assay followed the same immobilization technique of the BACE1 target as the phage display; recreating the same conditions encountered during the peptide isolation steps. The synthetic peptide was biotinylated at the $C$-terminus allowing a streptavidin/HRP conjugate to bind, providing a visual representation of the target binding produced with the OPD substrate. The same stringency was used in both the assay and biopanning round 5 to confirm the binding affinity between the peptide and target.

The colorimetric response, as a result of peptide binding to the BACE1 target, increased significantly when compared with the no peptide control. As the peptide concentration increased, so did the response to binding. In comparison to the negative control, containing no peptide, the $1 \mathrm{nM}$ test sample showed a significant increase in the amount of response generated (negative control $0.05 \pm 0.004 \mathrm{n}=3,1 \mathrm{nM} \mathrm{0.158} \pm 0.11, \mathrm{n}=3, \mathrm{p}=0.001, \mathrm{t}=8.58$ ) (Fig. 1). The peptide concentration was increased 10 -fold, to $10 \mathrm{nM}$ and $100 \mathrm{nM}$, which generated more binding with the BACE1 target $(10 \mathrm{nM} 0.39 \pm 0.03, \mathrm{n}=3, \mathrm{p}=0.0005, \mathrm{t}=10.44,100 \mathrm{nM} 0.88 \pm 0.01$, $\mathrm{n}=3, \mathrm{p}=0.000001, \mathrm{t}=76.37$ ). All experimental variables from $1 \mathrm{nM}$ to $100 \mathrm{nM}$ concentration, showed strong binding was occurring between the peptide and the immobilised BACE1 
target. Blocking buffer and microtitre plate binding controls (data not shown) did not show any attachment by the peptide.

Specificity Test of the Peptide Candidate to BACE1

The BACE1 translated protein shows sequence homology with BACE2 (52\%), renin (24\%) and cathepsin D (29\%), which can be cause for unwanted treatment side effects by means of nonspecific binding (33). To confirm peptide/BACE1 affinity, target specificity was performed on BACE2, renin and cathepsin D by using the same direct binding assay method as used previously for BACE1. All targets were immobilised on corresponding wells of a microtitre plate and introduced to a $100 \mathrm{nM}$ solution containing the peptide. As seen in the original binding assay, the peptide showed a strong affinity for BACE1 (negative control 0.057 \pm 0.0006 , $\mathrm{n}=3$, BACE1 $0.997 \pm 0.027, \quad \mathrm{n}=3$, $\mathrm{p}=0.000004, \mathrm{t}=34.45$ ). However, there was also significant colorimetric response to both cathepsin D $(0.08 \pm 0.006, n=3$, $\mathrm{p}=0.013, \mathrm{t}=4)$ and BACE2 $(0.221 \pm 0.014$,

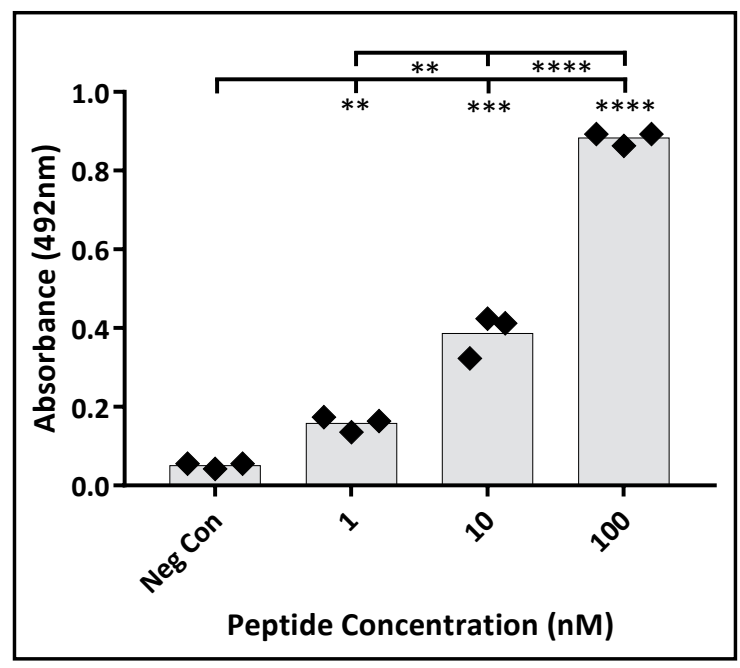

Fig. 1. The identified peptide shows a strong binding affinity for BACE1. The immobilised BACE1 target was introduced to $1 \mathrm{nM}, 10 \mathrm{nM}$ and $100 \mathrm{nM}$ solutions containing biotinylated peptide identified from the phage display and biopanning. Negative control (Neg Con) represents the response without a peptide. Total binding between the immobilized target and peptide is represented by a colorimetric response. All values are reported as individual data points $(n=3)$ and bars represent mean binding. Statistical significance is determined by unpaired Student's t-test $(\mathrm{p}<0.05 *$, $\mathrm{p}<0.01^{* *}, \mathrm{p}<0.001^{* * *}, \mathrm{p}<0.0001^{* * * *}$ ).
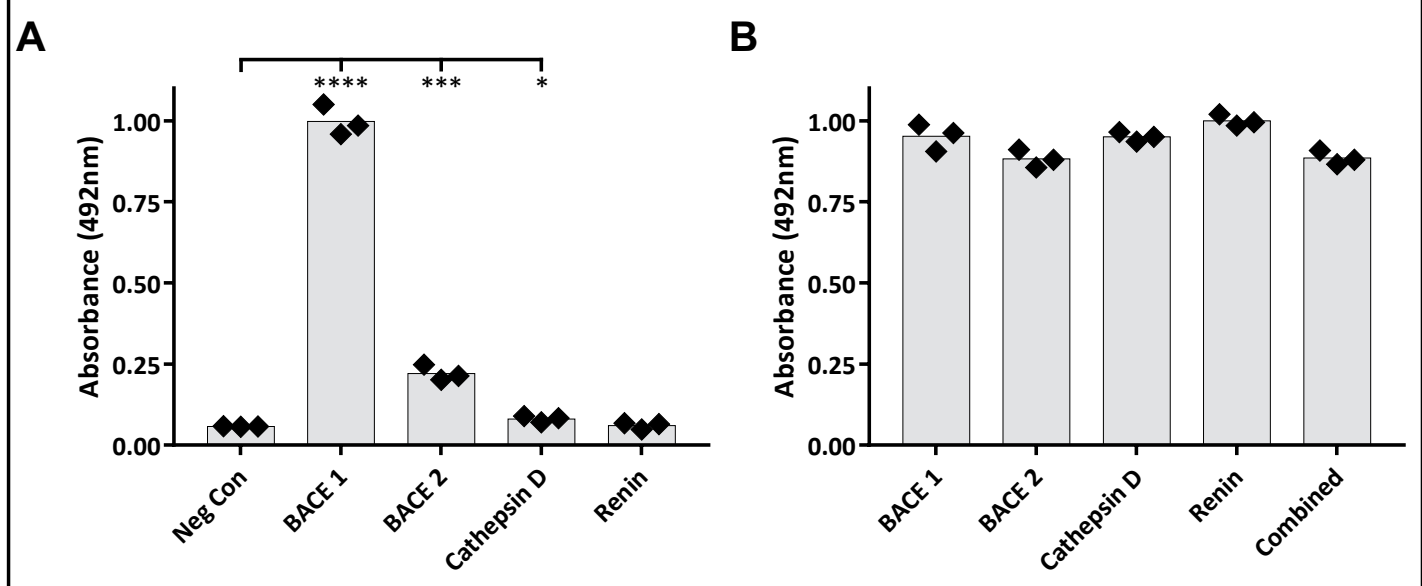

Fig. 2. Identified peptide has a specific affinity to BACE1 when incubated with homologous BACE2, cathepsin D and renin. (a) Immobilised BACE1, BACE2, cathepsin D and renin were incubated with a 100nM solution containing the peptide isolated from the phage display and biopanning experiments. (b) Testing overall peptide affinity for BACE1, individual homologs were preincubated with the peptide then incubated to an immobilized BACE1. A combined solution containing all homologs represents the total non-specific binding potential with these specific proteins. The binding occurring between the immobilized target and peptide is represented by an increase in colorimetric response. All values are reported as individual data points $(n=3)$ and the bars represent mean binding. Statistical significance is determined by unpaired Student's t-test $\left(\mathrm{p}<0.001^{* * *}, \mathrm{p}<0.0001^{* * * *}\right)$. 
$\mathrm{n}=3, \mathrm{p}=0.0003, \mathrm{t}=11.6$ ), albeit much lower than that of BACE1. The only target to not show a significant increase in binding was renin (0.06 $\pm 0.006, n=3, p=0.64, t=0.49)$ (Fig. 2a).

To confirm the strong BACE1 specific affinity, BACE2, renin and cathepsin D were pretreated with peptide prior to the reaction, allowing a possible binding to occur. The pretreatment was then transferred to wells containing immobilised BACE1 for the direct ELISA to determine the selective nature of the peptide and whether there is an affinity for BACE1 over the homologs. To exacerbate any potential binding, the peptide was also pre-treated in solution with a combination of renin, cathepsin D and BACE2. Pre-treating the peptide with cathepsin D had a minimal effect on subsequent binding to BACE1. This was the same for renin and BACE2 with the responses showing no significant difference to the BACE1 control. The potential binding to BACE2 $(0.88 \pm 0.02, n=3, p=0.076, t=2.372)$, cathepsin $\mathrm{D}(0.95 \pm 0.009$, $\mathrm{n}=3, \mathrm{p}=0.95, \mathrm{t}=0.064)$, or renin $(1.0 \pm 0.01, \mathrm{n}=3, \mathrm{p}=0.14, \mathrm{t}=1.82)$, was also negated as the peptide would bind strongly to BACE1 once it was in contact. Binding occurring between immobilised BACE1 target and peptide was maintained across all experimental wells (Fig. 2b). With all homologs added as a combination experiment, there was no significant decrease in response created by the pre-treatment, and the binding between the peptide and BACE1 remained consistent (BACE1 0.952 $\pm 0.024, n=3$, combined 0.8847 $\pm 0.012, n=3$, $\mathrm{p}=0.071, \mathrm{t}=2.44)$.

\section{BACE1 Activity Assay with Direct Binding Method}

Testing the BACE1 specific peptide for inhibitory properties in vitro was determined by simulating the in vivo pathway. Using a 7-methoxycoumarin labelled APP fragment as a substrate, cleavage by BACE1 was expressed by activation of the fluorophore and a representation of activity. The peptide was immobilised on nitrocellulose before being introduced to the experimental solution containing BACE1 and APP to determine preferential binding. The immobilised peptide was removed, along with any bound BACE1, before the fluorometric analysis was performed. The addition of a BACE1 specific peptide to the reaction reduced the amount substrate cleavage maintaining the quenched fluorophore. Initially, the $1 \mathrm{nM}$ concentration sample of immobilised peptide did not significantly reduce to the amount of substrate cleavage (negative control $0 \mathrm{nM} 117.4 \pm 3.64, \mathrm{n}=3,1 \mathrm{nM} 117.5 \pm 4.6, \mathrm{n}=3, \mathrm{p}=0.99$, $\mathrm{t}=0.005)$. However, $10 \mathrm{nM}$ showed a significant $23 \%$ reduction $(90.64 \pm 5.0, \mathrm{n}=3, \mathrm{p}=0.012$, $\mathrm{t}=4.33$ ) in the amount of substrate being cleaved. The response was reduced further by $44 \%$ (65.86 $\pm 1.37, n=3, p=0.0002, t=13.28)$ with a 10 -fold increase in peptide concentration to $100 \mathrm{nM}$ (Fig. 3). The increase in peptide concentration was causing a decrease of fluorescent response, which represented cleavage of the substrate, determined at an $\mathrm{IC}_{50}$ of $235.2 \mathrm{nM}$.

\section{A $\beta$ Assays from Treated Cells - SY5Y Cell Viability Test with BACE1 Specific Peptide} Treatment

To test the peptide for possible toxicity on neurons, SY5Y cells were treated with $1 \mathrm{nM}$, $10 \mathrm{nM}$ and $100 \mathrm{nM}$ of BACE1 specific peptide. Cell viability was measured using Trypan blue to confirm live cell numbers. The $1 \mathrm{nM}$ (negative control $0 \mathrm{nM} 91.33 \pm 0.33, \mathrm{n}=3,1 \mathrm{nM} 92.67 \pm 1.2$, $\mathrm{n}=3, \mathrm{p}=0.345, \mathrm{t}=1.07), 10 \mathrm{nM}(91.0 \pm 2.08, \mathrm{n}=3, \mathrm{p}=0.88, \mathrm{t}=0.16)$ and $100 \mathrm{nM}(93.67 \pm 1.33, \mathrm{n}=3$, $\mathrm{p}=0.164, \mathrm{t}=1.7$ ) treatments of BACE1 specific peptide did not exhibit a significant decrease in percentage of live cells when compared to the no treatment, negative control (Fig. 4a).

\section{SY5Y Cell Viability Test for $\mathrm{H}_{2} \mathrm{O}_{2}$ and BACE1 Inhibitor Treatment}

Oxidative stress is one of the earliest events in the initiating phases of $\mathrm{AD}(34) . \mathrm{H}_{2} \mathrm{O}_{2}$ induced oxidative stress is an important component of $A \beta$ deposition and can be an early indicator of neuronal cytotoxicity $(35,36)$. Simulating this oxidative stress event with $\mathrm{H}_{2} \mathrm{O}_{2}$ treatments can increase the production of $A \beta$ in SY5Y cells (37). The increase of oxidative stress on the cell can cause an apoptotic response leading to a decrease in viability. The aim of this study was to treat the cells with $\mathrm{H}_{2} \mathrm{O}_{2}$ to induce $A \beta$ release, without triggering the apoptotic response and determine the effect the BACE1 specific peptide could have on $\mathrm{A} \beta$ production. The cells were treated with both $\mathrm{H}_{2} \mathrm{O}_{2}$ and one of the $1 \mathrm{nM}$ (negative control 


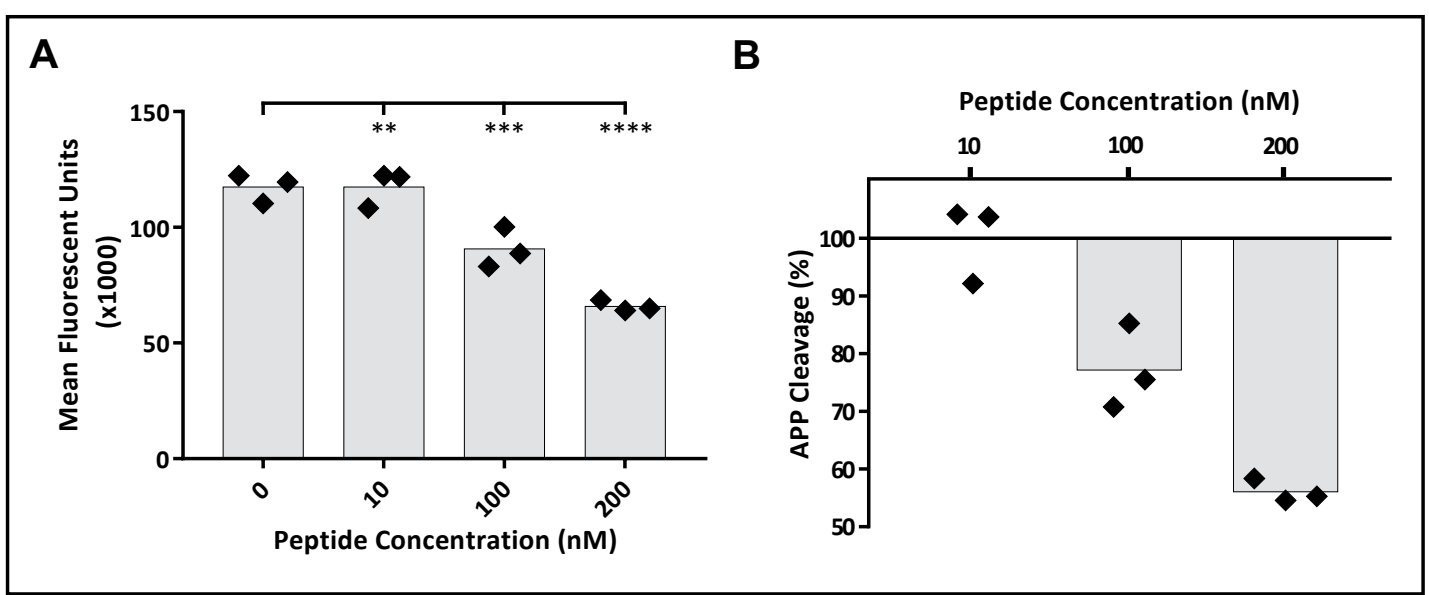

Fig. 3. The BACE1 specific peptide, when introduced to BACE1, can prevent the cleavage of an APP substrate. The BACE1 specific peptide was immobilised on nitrocellulose at concentrations of 10nM, 100nM and 200nM, respectively and introduced to a solution of APP substrate and BACE1. Quantification of mean fluorescence (a) represents the amount of APP cleavage. Percentage of APP cleavage reduction (b) signifies the BACE1 activity after incubation with the immobilised peptide. This data was compared to the negative control as a baseline $(n=3)$. All values are reported as individual data points $(n=3)$ and bars represent mean fluorescence. Statistical significance is determined by unpaired Student's t-test $(\mathrm{p}<0.01 * *, \mathrm{p}<0.001 * * *$, $\left.\mathrm{p}<0.0001^{* * * *}\right)$.

A

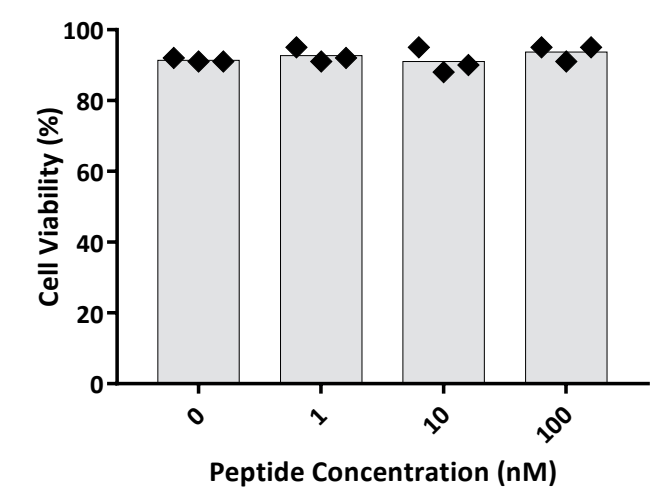

B

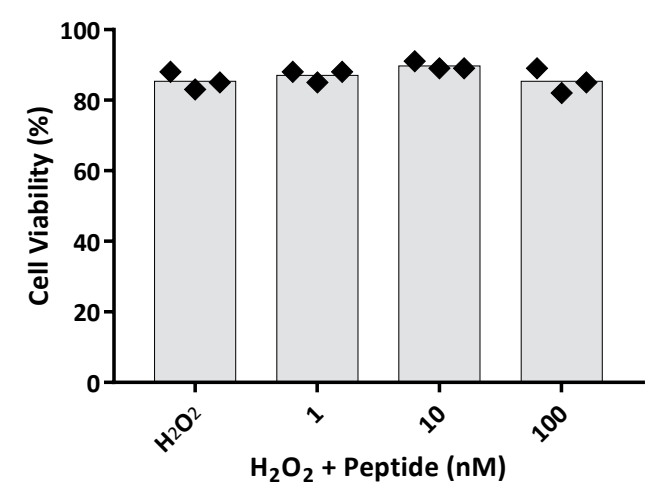

Fig. 4. Treatments with the BACE1 specific peptide does not cause a decrease in SY5Y cell viability. (a) Confluent SY5Y cells were tested for potential toxic effects by apoptosis due to treatments of $1 \mathrm{~nm}, 10 \mathrm{nM}$ and $100 \mathrm{nM}$ peptide in the media. (b) Co-treatment effects of and $\mathrm{H}_{2} \mathrm{O}_{2}$ induced oxidative stress with $1 \mathrm{~nm}, 10 \mathrm{nM}$ and $100 \mathrm{nM}$ concentrations of peptide determined by cell viability percentage of live cells. Percentage data was generated by cell counts of live and dead cells $(n=3)$. All values are reported as individual data points $(n=3)$ and bars represent the mean percentage of live cells from individual flasks.

0nM 85.33 $\pm 1.45, \mathrm{n}=3,1 \mathrm{nM} 87.0 \pm 1, \mathrm{n}=3, \mathrm{p}=0.398, \mathrm{t}=0.94), 10 \mathrm{nM}(89.67 \pm 0.67, \mathrm{n}=3, \mathrm{p}=0.054$, $\mathrm{t}=2.71)$ and $100 \mathrm{nM}(85.33 \pm 2.03, \mathrm{n}=3, \mathrm{p}>0.99, \mathrm{t}=0)$ concentrations of BACE1 specific peptide for 24 hours. Viability, as a result of the BACE1 inhibitor treatments, was not compromised as there was no significant increase or decrease in the number of live cells (Fig. 4b).

\section{$A \beta$ Production by SY5Y Cells are Reduced with BACE1 Inhibitor Treatment}

SY5Y cells naturally produce $A \beta$ in culture, which can be identified by ELISA. Capture antibodies bind to free $A \beta$ released when the cells are lysed. The fluctuations in APP processing by BACE 1 are determined by the increase or decrease of A $\beta$ production. The cells 


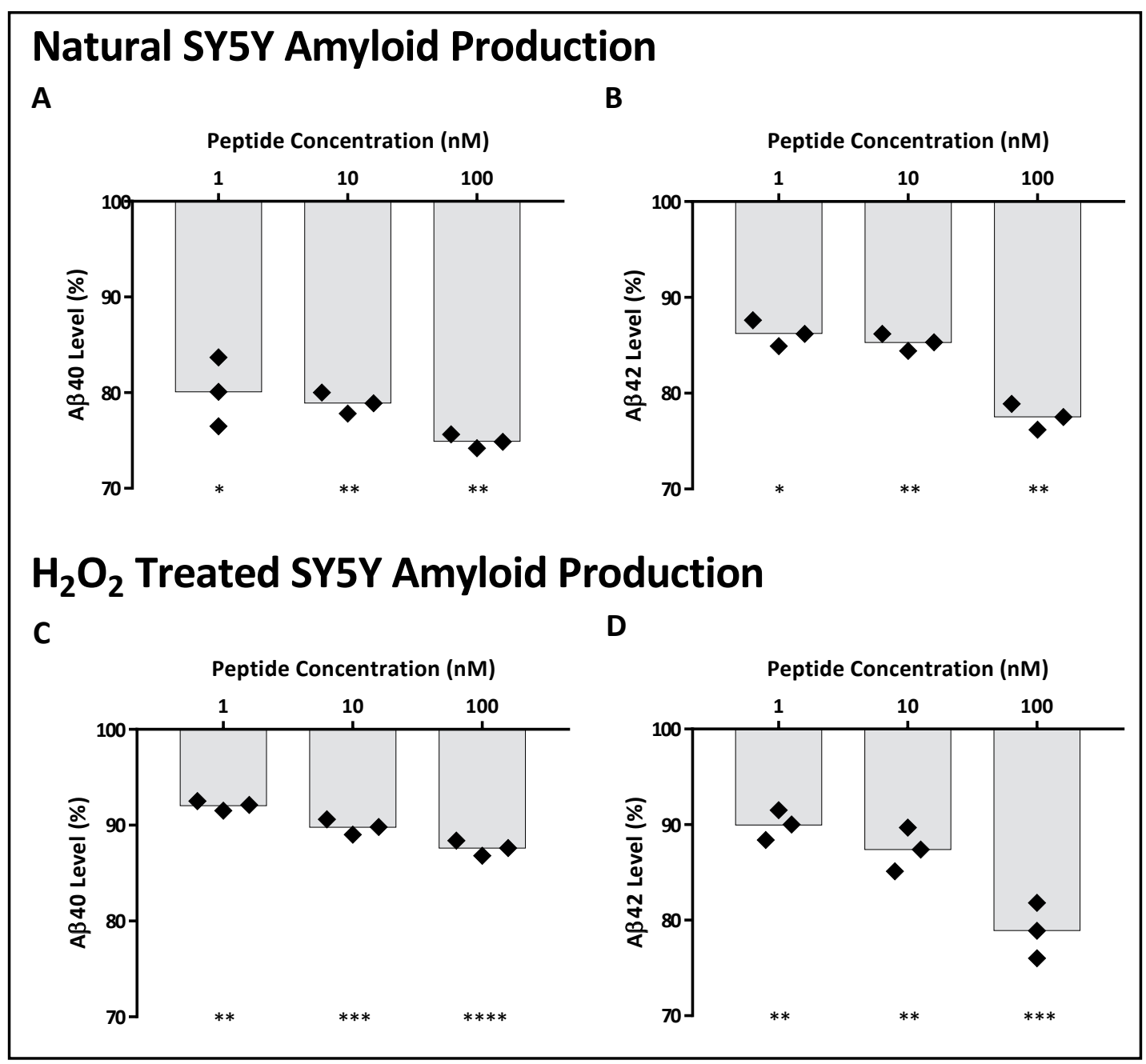

Fig. 5. BACE1 specific peptide treatment of SY5Y cells reduces the amount of $A \beta 40$ and A 342 production. SY5Y cells grown to confluence were treated with concentrations of BACE1 specific peptide at 1nm, 10nM and $100 \mathrm{~nm}$ in media. Naturally grown cells were tested with inhibitor and analysed by ELISA for (a) A $\beta 40$ and (b) A 342 . Testing for oxidative stress on SY5Y cells and potential for amyloid control by BACE1 specific peptide treatment at concentrations of $1 \mathrm{nM}, 10 \mathrm{nM}$ and $100 \mathrm{nM} . \mathrm{H}_{2} \mathrm{O}_{2}$ induced stress on treated cells were tested by ELISA for the production of (c) $A \beta 40$ and (d) A 342 and calculated for the percentage reduction as a result of the treatment. All values are reported as individual data points $(n=3)$ and bars represent mean percentage reduction. Statistical significance on raw data where treatments are compared to the negative control is determined by unpaired Student's t-test $\left(\mathrm{p}<0.05^{*}, \mathrm{p}<0.01^{* *}, \mathrm{p}<0.001^{* * *}, \mathrm{p}<0.0001^{* * * *}\right)$.

were treated with the BACE1 specific peptide to influence these fluctuations and to reduce the $A \beta$ loading. Both the $A \beta 40$ and $A \beta 42$ produced by the cells were significantly reduced after the treatment with BACE1 inhibitor. Cellular $A \beta 40$ levels were decreased by $20 \%$ with a $1 \mathrm{nM}$ treatment (negative control $0 \mathrm{nM} 0.595 \pm 0.009, \mathrm{n}=3,1 \mathrm{nM} 0.477 \pm 0.01, \mathrm{n}=3, \mathrm{p}=0.001, \mathrm{t}=7.83$ ), $21 \%$ for $10 \mathrm{nM}(0.47 \pm 0.004, \mathrm{n}=3, \mathrm{p}=0.0001, \mathrm{t}=13.3)$ and $25 \%$ for $100 \mathrm{nM}(0.446 \pm 0.003, \mathrm{n}=3$, $\mathrm{p}=0.00008, \mathrm{t}=16.53$ )(Fig. 5a). The 10 -fold increase in peptide treatment, from $10 \mathrm{nM}$ to $100 \mathrm{nM}$, significantly reduced the amount of $A \beta 40(\mathrm{p}=0.006, \mathrm{t}=5.26)$. The cellular $A \beta 42$ also showed a similar trend with significant reductions of $14 \%$ for $1 \mathrm{nM}$ (negative control $0 \mathrm{nM}$ $0.218 \pm 0.005, \mathrm{n}=3,1 \mathrm{nM} 0.188 \pm 0.002, \mathrm{n}=3, \mathrm{p}=0.004, \mathrm{t}=6.082), 15 \%$ for $10 \mathrm{nM}(0.186 \pm 0.001$, $\mathrm{n}=3, \mathrm{p}=0.003, \mathrm{t}=6.72)$ and $22 \%$ for $100 \mathrm{nM}(0.169 \pm 0.002, \mathrm{n}=3, \mathrm{p}=0.0006, \mathrm{t}=9.93)$, albeit with a very low signal produced by the ELISA (Fig. 5b). 


\section{Cellular Physiology Cell Physiol Biochem 2019;53:413-428 \\ \begin{tabular}{ll|l} 
and Biochemistry & $\begin{array}{l}\text { DOblished online: } 16 \text { August } 2019 \\
\text { Publis }\end{array}$ & $\begin{array}{l}\text { C } 2019 \text { The Author(s). Published by } \\
\text { Cell Physiol Biochem Press GmbH\&Co. KG }\end{array}$
\end{tabular} \\ Read et al.: Peptide Inhibitor of BACE1 for AD}

$\mathrm{H}_{2} \mathrm{O}_{2}$ Treatment of SY5Y Cells Increase A $\beta$ Production but is Reduced by BACE1 Inhibitor

Oxidative stress placed on the SY5Y cells produces an increase in the amount of $A \beta$ monomers. Cell treatments with $\mathrm{H}_{2} \mathrm{O}_{2}$ to induce oxidative stress, increased the amount $\mathrm{A} \beta$, which is an indication of more BACE1 cleavage of APP. Treatment of SY5Y cells with $\mathrm{H}_{2} \mathrm{O}_{2}$ increased the amount of $A \beta 40$ by $11 \%$ and $A \beta 4251 \%$, when compared to the untreated groups. The BACE1 specific peptide was added to the reaction aimed at controlling the amount of $A \beta$ produced under stress. $A \beta 40$ levels decreased by $8 \%$ with $1 \mathrm{nM}$ of the BACE1 specific peptide (negative control $0 \mathrm{nM} 0.657 \pm 0.001, \mathrm{n}=3,1 \mathrm{nM} 0.605 \pm 0.002, \mathrm{n}=3$, $\mathrm{p}=0.00004, \mathrm{t}=19.73), 10 \%$ with $10 \mathrm{nM}(0.59 \pm 0.003, \mathrm{n}=3, \mathrm{p}=0.00004, \mathrm{t}=19.9)$ and $12 \%$ with $100 \mathrm{nM}(0.576 \pm 0.003, \mathrm{n}=3, \mathrm{p}=0.00002, \mathrm{t}=22.53)$ (Fig. $5 \mathrm{c})$. A $\beta 42$ levels decreased by $10 \%$ with $1 \mathrm{nM}$ of BACE1 specific peptide (negative control 0nM $0.329 \pm 0.008, \mathrm{n}=3,1 \mathrm{nM} 0.296 \pm 0.003$, $\mathrm{n}=3, \mathrm{p}=0.01, \mathrm{t}=4.104), 13 \%$ with $10 \mathrm{nM}(0.287 \pm 0.004, \mathrm{n}=3, \mathrm{p}=0.009, \mathrm{t}=4.79)$ and $21 \%$ with $100 \mathrm{nM}(0.26 \pm 0.005, \mathrm{n}=3, \mathrm{p}=0.002, \mathrm{t}=7.48)$ (Fig. $5 \mathrm{~d}$ ). The more peptide added to the reaction, the less $A \beta$ monomers were being produced.

\section{Discussion}

Successful identification of a peptide with natural binding affinity for BACE1 was obtained using the phage display and biopanning techniques. Utilizing the M13 bacteriophage PIII surface protein, normally fundamental for F-pilus binding to host bacterial cells, gene modification allows for the expression of a small peptide sequence to be added without the loss of function (38). Refining the library of $1.1 \times 10^{9}$ different peptide sequences expressed on the PIII protein allowed for natural binding affinity to occur and identification of that specific sequence. Performing the higher stringency of the 5 biopanning rounds, instead of the usual 3, removed any non-specific candidates. Performing the amplified eluate consistently increased titre, as the biopanning rounds became more stringent, suggesting the pool of phage was being enriched. The transduction of phage DNA to the ER2738 E. coli host strain transferred the LacZ gene represented by the production of blue plaques, denoting the metabolism of X-gal. The metabolism of X-gal, included in the LB agar plates, was generated by the expression of the $\beta$-galactosidase enzyme, which caused plaques to develop a blue colour. The fifth round eluate did not contain any white plaques indicating that aseptic techniques were maintained throughout the experiments. The 12 blue plaques, from the biopanning round 5 unamplified eluate, produced a consistent sequence motif via DNA sequencing. The possibility of picking the wild-type phage was rejected as the plaques picked were blue in colour and maintained the insert, consistent with the M13KE cloning vector and triple glycine leader sequence.

The phage DNA insert sequence was translated and produced into a more pharmacologically friendly free synthetic peptide structure, without the connected phage, and reaffirmed for the binding shown in the biopanning rounds. Using a biotin tag on the peptide, the amount of binding was recorded by colorimetric assay, allowing for the natural binding affinity to BACE1 to still occur. Using peptide concentrations of $1 \mathrm{nM}, 10 \mathrm{nM}$ and $100 \mathrm{nM}$, each 10-fold increase was significantly higher than the previous, even when using the higher stringency wash conditions in the final round of biopanning. The direct assay is highly specific as the peptide can only bind to one of the protein target or blocking buffer, but the negative, no BACE1, control provided no colorimetric response which explains that specific binding was confirmed.

The cross reactivity of a BACE1 inhibitor to the closely related BACE2, renin and cathepsin D can cause potentially harmful adverse reactions as part of a treatment. The significant binding and inhibition of renin could alter cardiac output and systemic blood flow while alteration of cathepsin D activity can influence cell signalling and apoptosis $(39,40)$. The specificity assay was designed to test for potential cross reactivity by immobilizing one of the homologs, the same as for BACE1, and allowed to freely bind the peptide candidate. The peptide did not show any affinity to renin but cathepsin D and BACE2 produced a significant 


\section{Cellular Physiology Cell Physiol Biochem 2019;53:413-428 \\ \begin{tabular}{ll|l} 
and Biochemistry Published online: 16 August 2019 & $\begin{array}{l}\text { C } 2019 \text { The Author(s). Published by } \\
\text { Cell Physiol Biochem Press GmbH\&Co. KG }\end{array}$ \\
\hline
\end{tabular} \\ Read et al.: Peptide Inhibitor of BACE1 for AD}

increase in binding when compared with the negative control. However, when the peptide was pre-incubated in solution with a combination of homologs then added to a plate-wellimmobilised BACE1, the peptide no longer exhibited the cross-reactive effects. The binding to BACE1 was consistent across all experimental groups. These results give confidence when exposing the peptide to an in vivo environment that binding may not occur to these homologous proteins.

The peptide showed a binding affinity for BACE1 specifically, even in the presence of similar enzymes, but required the ability to inhibit the cleavage of APP to prevent production of the plaque forming $A \beta$ biproducts. The peptide was immobilised on nitrocellulose before the BACE1 activity reaction could take place to prevent unwanted background responses. The BACE1 substrate and nitrocellulose bound peptide were incubated together to determine the amount fluorometric response, which is an indicator of enzymatic activity. The APP fragment, maintained between the 7-methoxycoumarin-4-acetyl fluorophore and the 2, 4-dinitrophenyl quencher, was cleaved by the active BACE1, which triggered the fluorometric response. The negative control did not contain any BACE1 specific peptide and produced the highest amount of substrate cleavage. The amount of inhibition increased significantly with the 10 -fold addition of peptide. The peptide was able to bind to BACE1 and, as a consequence, APP cleavage was reduced.

Common inhibitor complications involved with using small permeable chemicals and antibodies are centred around specificity, binding affinity and toxicity. In an aim to identify a potential acute toxic affect as a result of the treatment, cell viability was determined. Using the SY5Y human neuroblast cell line in culture, treatments were given in media to identify any cell death that may be a consequence. The effective direct binding seen in the assays gave a precedent for the treatment dose, with the expectation that it could bind to membrane bound BACE1. As a result, there was no significant cell death caused by the treatments and visual physiology did not show dysfunction. This gives a confidence that the peptide is well accepted by this human neuronal cell type. In the interest of usage and the effective concentrations exhibited in both the direct binding and activity assays, LD50 was not determined however, it would be more appropriate when used in an in vivo model. The use of a viability test gives an understanding that there is no acute toxicity associated with the treatment. However, this could be better understood using proteomics and RNASeq techniques to ascertain potential changes occurring. In terms of peptide specific BACE1 inhibition and the possible repercussions, knockout studies have shown that there is minimal cellular dysfunction with the lack of the gene, regardless of the potential for incomplete inhibition $(41,42)$.

Confident in the treatment concentrations from the direct assays, BACE1 activity, and the $A \beta$ produced as a consequence, was tested with addition of the BACE1 specific peptide as an intervention strategy. As there was no observable toxicity generated by the viability test, the same concentrations were used. Using this result as the background for treatment on normally functioning healthy cells, the peptide was able to significantly reduce $A \beta$ production at nanomolar concentrations. While the response levels were viable but low, especially for $A \beta 42$, there was still a significant reduction suggesting that in a non-diseased state there is an effectiveness for the peptide. Samples treated with a $100 \mathrm{nM}$ concentration of BACE1 specific peptide incorporated into the media was able to reduce $A \beta 40$ by $25 \%$ and A $\beta 42$ by $22 \%$.

The onset of $\mathrm{AD}$ is met by the accumulation of neurofibrillary tangles and amyloid plaques with the underlying pressure of oxidative stress (43). The deposition of plaques and tangles cause significant damage to surrounding cells by triggering a feedback loop. Under conditions of oxidative stress, the SY5Y cells have been reported to influence APP processing by increasing the amount of cytosolic $A \beta$ (44). In this study, SY5Y cells were treated with $\mathrm{H}_{2} \mathrm{O}_{2}$ to simulate stress to increase the cleavage of APP. The cells were tested both with and without $\mathrm{H}_{2} \mathrm{O}_{2}$ and both produced a significant amount of $A \beta 40$ and $A \beta 42$. The treatment of $\mathrm{H}_{2} \mathrm{O}_{2}$ did not affect cell viability or observable physiology, even with the extra stress, but did significantly increase the amount of $A \beta$ produced above that of the untreated cells. The possibility for toxic effects while already stressed would have been shown with a decrease 


\section{Cellular Physiology Cell Physiol Biochem 2019;53:413-428 \\ \begin{tabular}{ll|l} 
and Biochemistry & $\begin{array}{l}\text { DOl: 10.33594/000000147 } \\
\text { Published online: } 16 \text { August } 2019\end{array}$ & $\begin{array}{l}\text { O } 2019 \text { The Author(s). Published by } \\
\text { Cell Physiol Biochem Press GmbH\&Co. KG }\end{array}$ \\
\cline { 2 - 3 } &
\end{tabular} \\ Read et al.: Peptide Inhibitor of BACE1 for AD}

in the number of live cells, however it was not observed with this model. Adding $100 \mathrm{nM}$ of BACE1 specific peptide to the media treatment elicited a $12 \%$ reduction in $A \beta 40$ and $21 \%$ of $A \beta 42$. Even with $A \beta 42$ being produced in less amounts, it is the more amyloidogenic of the two, maintaining a higher binding affinity for other $A \beta$ fragments (38-43) causing acute plaque generation (45-47). These reductions in BACE1 activity may be further reduced with higher peptide inhibitor concentration treatments.

For the peptide to be successful in preventing this pathway, it would need to remain unchanged within the media for the 24-hour time period. To apply maximum effectiveness, the peptide needs to bind to BACE1 and inhibit the cleavage of APP while being able to transport across the membrane into the cell. The BACE1 specific peptide was able to reduce BACE1 activity within the SY5Y neuronal cell line while under oxidative stress, thus generating less of the oligomer producing $A \beta$. The reduction of cellular $A \beta$ could therefore, reduce the potential for plaque generation but would need to be tested in an in vivo model.

While showing effectiveness in a cellular model, inhibitor focus has been directed at chemicals with blood brain barrier permeability and oral availability. However, the requirement to develop a strong binding candidate is still an important direction. Using the phage display technique to identify a 12-residue peptide with significant binding properties at a high potency, we have successfully identified a new candidate for future investigation into a pharmaceutical intervention for the production of $\mathrm{AD}$ plaques, which may form as the backbone for a new treatment option. This method may not follow Lipinski's rule of 5 in terms of having a predictably viable and physiochemically ready backbone but further refining using alanine scanning and truncated peptide analysis in our future studies will help identify the most important residues and reduce the molecular weight (48). As it is a peptidic structure, there are many options for peptidomimetic modification without diminishing effectiveness.

\section{Conclusion}

In summary, with application of the phage display and biopanning techniques, a BACE1 specific peptide was successfully identified. Sequencing of phage DNA determined the expressed peptide on the capsid. The peptide was synthetically produced and tested successfully for a direct binding affinity to BACE1. A potential cross reactivity with the peptide and closely related BACE2, cathepsin D and renin was refuted using competition assays. The peptide also reduced the enzymatic cleavage of an APP-like substrate showing an ability to prevent BACE1 activity. Taking the peptide to a human neuronal cell culture did not cause any detriment to cell growth while being able to reduce the amount of $A \beta 40$ and $A \beta 42$. Inducing cells with oxidative stress via treatment with $\mathrm{H}_{2} \mathrm{O}_{2}$ challenged the normal cellular growth patterns without causing death, and when co-treated with inhibitor did not challenge viability. While the $\mathrm{H}_{2} \mathrm{O}_{2}$ treatments increased the amount of $A \beta 40$ and $A \beta 42$, the $B A C E 1$ specific peptide was able to significantly reduce their production. With the ability to reduce $A \beta$ in culture, the BACE1 specific peptide shows early promise in the treatment of plaque generation in $\mathrm{AD}$.

\section{Acknowledgements}

The study was supported by Deakin University Centre for Molecular and Medical Research (CMMR). Author J. Read was supported by Deakin University Postgraduate Award (DUPA). 


\section{Cellular Physiology Cell Physiol Biochem 2019;53:413-428 \begin{tabular}{l|l|l}
\cline { 2 - 3 } DOI: 10.33594/000000147 & (c) 2019 The Author(s). Published by
\end{tabular} and Biochemistry Published online: 16 August 2019 Cell Physiol Biochem Press GmbH\&Co. KG \\ Read et al.: Peptide Inhibitor of BACE1 for AD}

\section{Disclosure Statement}

The authors have no conflicts of interest.

\section{References}

1 Brun A, Englund E: Regional pattern of degeneration in Alzheimer's disease: neuronal loss and histopathological grading. Histopathology 1981;5:549-564.

2 Venneri A, Shanks MF, Bruen PD, McGeown WJ: Neuroanatomical correlates of neuropsychiatric symptoms in Alzheimer's disease. Brain 2008;131:2455-2463.

3 Glenner GG, Wong CW: Alzheimer's disease: Initial report of the purification and characterization of a novel cerebrovascular amyloid protein. Biochem Biophys Res Commun 1984;120:885-890.

4 Masters CL, Simms G, Weinman NA, Multhaup G, McDonald BL, Beyreuther K: Amyloid plaque core protein in Alzheimer disease and Down syndrome. Proc Natl Acad Sci U S A 1985;82:4245-4249.

5 Tanzi R, Gusella J, Watkins P, Bruns G, St George-Hyslop P, Van Keuren M, Patterson D, Pagan S, Kurnit DM, Neve RL: Amyloid beta protein gene: cDNA, mRNA distribution, and genetic linkage near the Alzheimer locus. Science 1987;235:880-884.

6 Kang J, Lemaire H-G, Unterbeck A, Salbaum JM, Masters CL, Grzeschik K-H, Multhaup G, Beyreuther K, Muller-Hill B: The precursor of Alzheimer's disease amyloid A4 protein resembles a cell-surface receptor. Nature 1987;325:733-736.

7 Hussain I, Powell D, Howlett DR, Tew DG, Meek TD, Chapman C, Gloger IS, Murphy KE, Southan CD, Ryan DM, Smith TS, Simmons DL, Walsh FS, Dingwall C, Christie G: Identification of a novel aspartic protease (Asp 2) as $\beta$-secretase. Mol Cell Neurosci 1999;14:419-427.

8 Sinha S, Anderson JP, Barbour R, Basi GS, Caccavello R, Davis D, Doan M, Dovey HF, Frigon N, Hong J, Jacobson-Croak K, Jewett N, Keim P, Knops J, Lieberburg I, Power M, Tan H, Tatsuno G, Tung J, Schenk D, et al.: Purification and cloning of amyloid precursor protein $\beta$-secretase from human brain. Nature 1999;402:537-540.

9 Vassar R, Bennett BD, Babu-Khan S, Kahn S, Mendiaz EA, Denis P, Teplow DB, Ross S, Amarante P, Loeloff R, Luo Y, Fisher S, Fuller J, Edenson S, Lile J, Jarosinski MA, Biere AL, Curran E, Burgess T, Louis JC,et al.: $\beta$-secretase cleavage of Alzheimer's amyloid precursor protein by the transmembrane aspartic protease BACE. Science 1999;286:735-741.

10 Jorissen E, Prox J, Bernreuther C, Weber S, Schwanbeck R, Serneels L, Snellinx A, Craessaerts K, Thathiah A, Tesseur I, Bartsch U, Weskamp G, Blobel CP, Glatzel M, De Strooper B, Saftig P: The disintegrin/ metalloproteinase ADAM10 is essential for the establishment of the brain cortex. J Neurosci 2010;30:48335844.

11 Citron M, Oltersdorf T, Haass C, McConlogue L, Hung AY, Seubert P, Vigo-Pelfrey C, Lieberburg I, Selkoe DJ: Mutation of the $\beta$ amyloid precursor protein in familial Alzheimer's disease increases $\beta$-protein production. Nature 1992;360:672-674.

12 Levy-Lahad E, Wasco W, Poorkaj P, Romano D, Oshima J, Pettingell W, Yu CE, Jondro PD, Schmidt SD, Wang K: Candidate gene for the chromosome 1 familial Alzheimer's disease locus. Science 1995;269:973-977.

13 Rogaev EI, Sherrington R, Rogaeva EA, Levesque G, Ikeda M, Liang Y, Chi H, Lin C, Holman K, Tsuda T: Familial Alzheimer's disease in kindreds with missense mutations in a gene on chromosome 1 related to the Alzheimer's disease type 3 gene. Nature 1995;376:775-778.

14 Sherrington R, Rogaev EI, Liang Y, Rogaeva EA, Levesque G, Ikeda M, Chi H, Lin C, Li G, Holman K, Tsuda T, Mar L, Foncin JF, Bruni AC, Montesi MP, Sorbi S, Rainero I, Pinessi L, Nee L, Chumakov I, et al.: Cloning of a gene bearing missense mutations in early-onset familial Alzheimer's disease. Nature 1995;375:754-760.

15 Borchelt DR, Thinakaran G, Eckman CB, Lee MK, Davenport F, Ratovitsky T, et al. Familial Alzheimer's disease-linked presenilin 1 variants elevat Aß1-42/1-40 ratio in vitro and in vivo. Neuron 1996;17:10051013.

16 Citron M, Westaway D, Xia W, Carlson G, Diehl T, Levesque G, Johnson-Wood K, Lee M, Seubert P, Davis A, Kholodenko D, Motter R, Sherrington R, Perry B, Yao H, Strome R, Lieberburg I, Rommens J, Kim S, Schenk $D$, et al.: Mutant presenilins of Alzheimer's disease increase production of 42-residue amyloid $\beta$-protein in both transfected cells and transgenic mice. Nat Med 1997;3:67-72. 


\section{Cellular Physiology Cell Physiol Biochem 2019;53:413-428 \begin{tabular}{ll|l|l|l}
\hline DOl: $10.33594 / 000000147$ & O 2019 The Author(s). Published by \\
\hline
\end{tabular} and Biochemistry Published online: 16 August 2019 Cell Physiol Biochem Press GmbH\&Co. KG \\ Read et al.: Peptide Inhibitor of BACE1 for AD}

17 Scheuner D, Eckman C, Jensen M, Song X, Citron M, Suzuki N, Bird TD, Hardy J, Hutton M, Kukull W, Larson E, Levy-Lahad E, Viitanen M, Peskind E, Poorkaj P, Schellenberg G, Tanzi R, Wasco W, Lannfelt L, Selkoe D, et al.: Secreted amyloid $\beta$-protein similar to that in the senile plaques of Alzheimer's disease is increased in vivo by the presenilin 1 and 2 and APP mutations linked to familial Alzheimer's disease. Nat Med 1996;2:864-870.

18 Cohen SIA, Linse S, Luheshi LM, Hellstrand E, White DA, Rajah L, Otzen DE, Vendruscolo M, Dobson CM, Knowles TP: Proliferation of amyloid- $\beta 42$ aggregates occurs through a secondary nucleation mechanism. Proc Natl Acad Sci USA 2013;110:9758-9763.

19 Spires-Jones TL, Mielke ML, Rozkalne A, Meyer-Luehmann M, de Calignon A, Bacskai BJ, Schenk D, Hyman BT: Passive immunotherapy rapidly increases structural plasticity in a mouse model of Alzheimer disease. Neurobiol Dis 2009;33:213-220.

20 Cleary JP, Walsh DM, Hofmeister JJ, Shankar GM, Kuskowski MA, Selkoe DJ, Ashe KH: Natural oligomers of the amyloid- $\beta$ protein specifically disrupt cognitive function. Nat Neuro 2005;8:79-84.

21 Hsieh H, Boehm J, Sato C, Iwatsubo T, Tomita T, Sisodia S, Malinow R: AMPAR removal underlies A $\beta$-induced synaptic depression and dendritic spine loss. Neuron 2006;52:831-843.

22 Suphioglu C, Sadli N, Coonan D, Kumar L, De Mel D, Lesheim J, Sinclair AJ, Ackland L: Zinc and DHA have opposing effects on the expression levels of histones H3 and H4 in human neuronal cells. Brit J Nutr 2009;103:344-351.

23 Kukucka J, Wyllie T, Read J, Mahoney L, Suphioglu C: Human neuronal cells: epigenetic aspects. Biomol Concepts 2013;4:319-333.

24 Lin YT, Seo J, Gao F, Feldman HM, Wen HL, Penney J, Cam HP, Gjoneska E, Raja WK, Cheng J, Rueda R, Kritskiy O, Abdurrob F, Peng Z, Milo B, Yu CJ, Elmsaouri S, Dey D, Ko T, Yankner BA, et al.: APOE4 causes widespread molecular and cellular alterations associated with Alzheimer's disease phenotypes in human IPSC-derived brain cell types. Neuron 2018;98:1141-1154.e7.

25 Read J, Suphioglu C. Dropping the BACE: Beta secretase (BACE1) as an Alzheimer's disease intervention target, in Kishore U (ed): Neurodegenerative Diseases. InTechOpen, London, 2013.

26 Peters F, Salihoglu H, Rodrigues E, Herzog E, Blume T, Filser S, Dorostkar M, Shimshek DR, Brose N, Neumann U, Herms J: BACE1 inhibition more effectively suppresses initiation than progression of $\beta$-amyloid pathology. Acta Neurol 2018;135:695-710.

27 Hsiao K, Chapman P, Nilsen S, Eckman C, Harigaya Y, Younkin S, Yang F, Cole G: Correlative memory deficits, $\mathrm{A} \beta$ elevation, and amyloid plaques in transgenic mice. Science 1996;274:99-103.

28 Ahmed N, Dhanapala P, Suphioglu C: Identification and characterization of a novel Il-4 receptor $\alpha$ chain (Il4ro) antagonist to inhibit Il-4 signalling. Cell Physiol Biochem 2015;36:831-842.

29 McCafferty J, Jackson RH, Chiswell DJ: Phage-enzymes: expression and affinity chromatography of functional alkaline phosphatase on the surface of bacteriophage. Protein Eng Des Sel 1991;4:955-961.

30 Ganesan R, Zhang Y, Landgraf KE, Lin SJ, Moran P, Kirchhofer D: An allosteric anti-hepsin antibody derived from a constrained phage display library. Protein Eng Des Sel 2012;25:127-133.

31 Bahudhanapati H, Zhang Y, Sidhu SS, Brew K: Phage display of tissue inhibitor of metalloproteinases-2 (timp-2): Identification of selective inhibitors of collagenase-1 (metalloproteinase 1 (mmp-1)). J Biol Chem 2011;286:31761-31770.

32 Lee YC, Hsiao NW, Tseng TS, Chen WC, Lin HH, Leu SJ, Yang EW, Tsai KC: Phage display-mediated discovery of novel tyrosinase-targeting tetrapeptide inhibitors reveals the significance of $\mathrm{N}$-terminal preference of cysteine residues and their functional sulfur atom. Mol Pharmacol 2015;87:218-230.

33 Yuan J, Venkatraman S, Zheng Y, McKeever BM, Dillard LW, Singh SB: Structure-based design of $\beta$-site app cleaving enzyme 1 (BACE1) inhibitors for the treatment of Alzheimer's disease. J Med Chem 2013;56:41564180 .

34 Atwood CS, Obrenovich ME, Liu T, Chan H, Perry G, Smith MA, Martins RN: Amyloid- $\beta$ : a chameleon walking in two worlds: a review of the trophic and toxic properties of amyloid- $\beta$. Brain Res Rev 2003;43:1-16.

35 Behl C, Davis JB, Lesley R, Schubert D: Hydrogen peroxide mediates amyloid $\beta$ protein toxicity. Cell 1994;77:817-827.

36 Tabner BJ, El-Agnaf OMA, Turnbull S, German MJ, Paleologou KE, Hayashi Y, Cooper LJ, Fullwood NJ, Allsop D: Hydrogen peroxide is generated during the very early stages of aggregation of the amyloid peptides implicated in Alzheimer disease and familial british dementia. J Biol Chem 2005;280:35789-35792. 


\section{Cellular Physiology Cell Physiol Biochem 2019;53:413-428

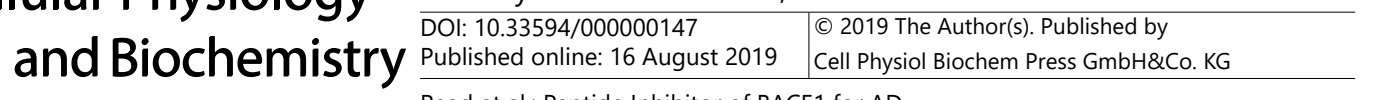 \\ Read et al.: Peptide Inhibitor of BACE1 for AD}

37 Misonou H, Morishima-Kawashima M, Ihara Y: Oxidative stress induces intracellular accumulation of amyloid $\beta$-protein $(A \beta)$ in human neuroblastoma cells. Biochemistry 2000;39:6951-6959.

38 Cwirla SE, Peters EA, Barrett RW, Dower WJ: Peptides on phage: a vast library of peptides for identifying ligands. Proc Natl Acad Sci USA 1990;87:6378-6382.

39 Benes P, Vetvicka V, Fusek M: Cathepsin D-Many functions of one aspartic protease. Crit Rev Oncol Hemat 2008;68:12-28.

40 de Man FS, Tu L, Handoko ML, Rain S, Ruiter G, François C, Schalij I, Dorfmüller P, Simonneau G, Fadel E, Perros F, Boonstra A, Postmus PE, van der Velden J, Vonk-Noordegraaf A, Humbert M, Eddahibi S, Guignabert C: Dysregulated renin-angiotensin-aldosterone system contributes to pulmonary arterial hypertension. Am J Resp Crit Care 2012;186:780-789.

41 Roberds SL, Anderson J, Basi G, Bienkowski MJ, Branstetter DG, Chen KS, Freedman SB, Frigon NL, Games D, Hu K, Johnson-Wood K, Kappenman KE, Kawabe TT, Kola I, Kuehn R, Lee M, Liu W, Motter R, Nichols NF, Power M, et al.: BACE knockout mice are healthy despite lacking the primary $\beta$-secretase activity in brain: implications for Alzheimer's disease therapeutics. Hum Mol Gen 2001;10:1317-1324.

42 Luo Y, Bolon B, Kahn S, Bennett BD, Babu-Khan S, Denis P, Fan W, Kha H, Zhang J, Gong Y, Martin L, Louis JC, Yan Q, Richards WG, Citron M, Vassar R: Mice deficient in BACE1, the Alzheimer's $\beta$-secretase, have normal phenotype and abolished $\beta$-amyloid generation. Nat Neuro 2001;4:231-232.

43 Tamagno E, Bardini P, Guglielmotto M, Danni O, Tabaton M: The various aggregation states of $\beta$-amyloid 1-42 mediate different effects on oxidative stress, neurodegeneration, and BACE-1 expression. Free Radical Bio Med 2006;41:202-212.

44 Tong Y, Zhou W, Fung V, Christensen MA, Qing H, Sun X, Song W: Oxidative stress potentiates BACE1 gene expression and $A \beta$ generation. J Neural Transm 2005;112:455-469.

45 Albani D, Polito L, Batelli S, De Mauro S, Fracasso C, Martelli G, Colombo L, Manzoni C, Salmona M, Caccia S, Negro A, Forloni G: The SIRT1 activator resveratrol protects SK-N-BE cells from oxidative stress and against toxicity caused by $\alpha$-synuclein or amyloid- $\beta$ (1-42) peptide. J Neurochem 2009;110:1445-1456.

46 Zheng L, Roberg K, Jerhammar F, Marcusson J, Terman A: Oxidative stress induces intralysosomal accumulation of Alzheimer amyloid $\beta$-protein in cultured neuroblastoma cells. Ann NY Acad Sci 2006;1067:248-251.

47 Dominguez D, Tournoy J, Hartmann D, Huth T, Cryns K, Deforce S, Serneels L, Camacho IE, Marjaux E, Craessaerts K, Roebroek AJ, Schwake M, D’Hooge R, Bach P, Kalinke U, Moechars D, Alzheimer C, Reiss K, Saftig P, De Strooper B: Phenotypic and biochemical analyses of BACE1- and BACE2-deficient mice. J Bio Chem 2005;280:30797-30806.

48 Lipinski CA: Lead- and drug-like compounds: the rule-of-five revolution. Drug Discov Today Technol 2004;1:337-341. 